\title{
Private and Government Partnership Yayasan Lengis Hijau and Denpasar City Government - Recycling used-cooking-oil into Bio-diesel for Gensets and School Buses
}

\author{
I.N.S. Kumara, I.A.D. Giriantari, W.G. Ariastina, W. Sukerayasa, E. Setiawan
}

\section{BACKGROUND}

Deep frying is a common way of food preparation in Indonesia, both at home and in hotels or restaurants. In Bali, it is estimated that around four million liters of usedcooking-oil (UCO) is produced by households alone and between 80 to 120 -kilo liter of UCO produced by hotels and restaurants. No figure on the volume of UCO produced by food stalls (streets stalls or warung) but the number is expected to be high due to a large number of street food stalls in the community. In short, a huge volume of UCO is produced by our kitchen activities.

Allegedly, many street traders (pedagang kaki lima)also re-use UCO as cooking oil for preparing their foods. The health impacts of the repetitive use of used-cooking-oil are well understood within the medical world but less on the general public due to long-term or slow effects on people's life and little efforts of the government to create or improve awareness among people. Excessive heating of foods leads to the production of polycyclic aromatic hydrocarbon (PAH) and free radicals which have carcinogenic effects that destroy food nutrients and potentially damaging our health.

If used-cooking-oil is released directly into nature without any treatments, it could cause pollution on the surface running water, destruction of water organisms, and soil.

Yayasan Lengis Hijau (YLH) comes to provide good solutions to overcome the problem of UCO.YLH has set up facilities in Denpasar City to recycle used-cooking-oil into bio-diesel. Currently, YLH operates in six districts: Badung, Bangli, Denpasar, Gianyar, Karangasem, and Tabanan.

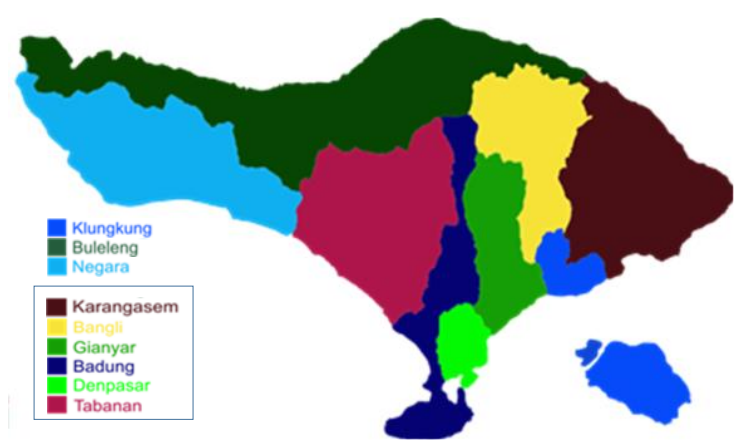




\section{Policy Recommendations}

- Establishing department in provincial level that focus on New and Renewable Energy and Energy Conservation Development for easier coordination and communication at the provincial level

- Setting up clear policy on waste management specifically for used-cooking-oil

- Greater campaign on health risk on the use of used-cooking-oil for food preparation

- Regulation regardingthe use of high content of biodiesel (B100) and vehicles' manufacturer quarantee

- Policy and incentives for consumers who use biodiesel

- Further research for biofuel real life performance tests, fuel efficiency, storage with regards to contamination and microorganism, effects of biodiesel on engine's parts, the use of fuel filters

- Research on improving existing catalyst or identifying new catalyst material for processing usedcooking-oil to become bio-diesel

- Establishing guidelines and mechanism for complying with 18 SNI standards on biodiesel production

Figure 1. The used-cooking-oil business area of YLH in Bali

By recycling used-cooking-oil into bio-diesel, it will reduce the consumption of fossil-based fuel hence reducing greenhouse gas emissions. It also prevents damaging soil and water should the used-cooking-oil is directly disposed into the environments. Further, in regulated usedcooking-oil management, it will prevent the risk of health due to the re-use of used-cooking-oil by street traders.

\section{THE PARTNERSHIP - private and government}

YLH is established as a partnership between the Government City of Denpasar, CARITAS Switzerland, Foundation myclimate, and Kuoni. YLH is a not-to-profit organization with a mission to protect the environment and public health through the management and processing of used-cooking-oil into bio-diesel. YLH also set to become a reliable partner in processing used-cookingoil into biodiesel (B100) as a clean and sustainable fuel. Caritas Switzerland is a multidisciplinary, mutual assistance, charitable organization with headquarters in Lucerne. Their international cooperation is based on facilitating independence in many areas including climate protection and crisis prevention. Foundation myclimate is a Swiss non-profits organization that works in the area of education and climate protection projects. KuoniTravel Holding Ltd is a travel holding company based in Zurich. These organizations worked together to establish the project and then developed $\mathrm{YLH}$ as a social enterprise to manage the project sustainably.

YLH was established on February 18, 2013. It was registered under Notarial Certificate No 71 dated on October 17, 2012, and Decree of Ministry of Law and Human Rights No AHU-2981.AH.01.04 year 2013. It was also registered under UKL/UPL No 660.1/1504/BLH. And Commercial License on BioFuel registered under PT. Bali Hijau Lestari Biodiesel No 503/2284/ESDM_DPU.

\section{TECHNOLOGY - biodiesel from used cooking oil}


There are several biodiesel fuels based on the composition of the mix such as B2, B5, B10, B20, and B100. B2 is a biofuel that contains $2 \%$ biofuel and $98 \%$ petroleum diesel. And B100 is a pure $100 \%$ biofuel. YLH produces only $\mathrm{B} 100$. $\mathrm{B} 20$ is a common biofuel in the United States. However, B100 biodiesel is less common due to a lack of regulation and pricing. The typical biodiesel process is shown in Fig 2.

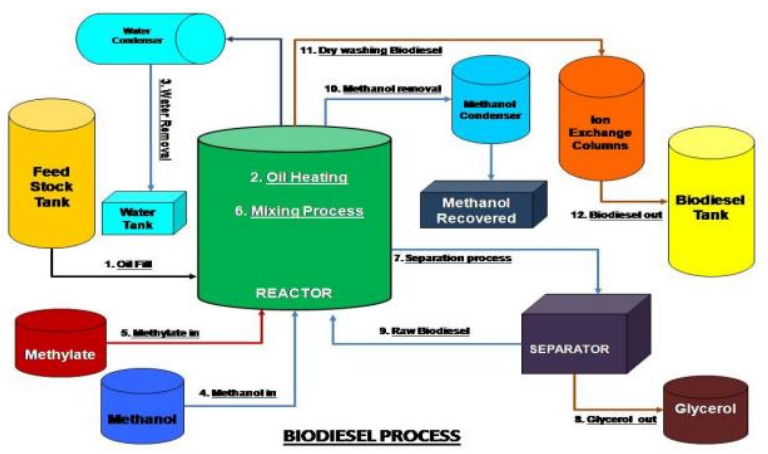

Fig. 2 Biofuel process

The biodiesel processing plant of YLH is shown in Fig 3. The plant is a Fuelmatic GSX 3 developed by Greenfuels Ltd, a company based in Gloucestershire, United Kingdom. The plant is built using stainless steel material and the system is CE/ATEX certified. Some features of Fuelmatic GSX3 are as follows:

- $\quad$ The processing equipment is able to use various cold and hot pressed fresh vegetable oils (some may require pre-treatment) and waste vegetable oil as feedstock.

- Using the specified quantity and quality of input materials (feedstock, alcohol, and catalyst) and following processing instructions, the plant operator/owner will achieve biodiesel which complies with the EU biodiesel standard EN 14214, as well as with other conventional international standards like ASTM D6751. With most feedstocks, a transesterification grade of $>98 \%$ and consistent product quality will be reached.

- The FuelMatic GSX requires no water for biodiesel purification (soap removal). Older technology processors use water to wash the soap from biodiesel. In the FuelMatic GSX, purification is achieved by passing the biodiesel through Ion exchange resin. This purification process produces only very small quantities of waste products, as $1 \mathrm{~kg}$ of ion-exchange resin will purify between 1,000 1,500 liters of raw biodiesel.

The main process as described by Greenfuelscan be summarized as follows:

- The feedstock is heated, then measured into the reaction vessels where methanol and methylate are accurately injected into the flow.

- Once the reaction is complete the mixture of crude biodiesel and crude glycerin is channeled through to the GSX separation unit where the two products are clearly separated and the glycerine is discharged to storage.

- The crude biodiesel then passes through the purification process where any impurities are removed through an ion exchange process.

- Finally, the residual methanol is recovered for reuse and the resulting biodiesel is automatically discharged to site storage.

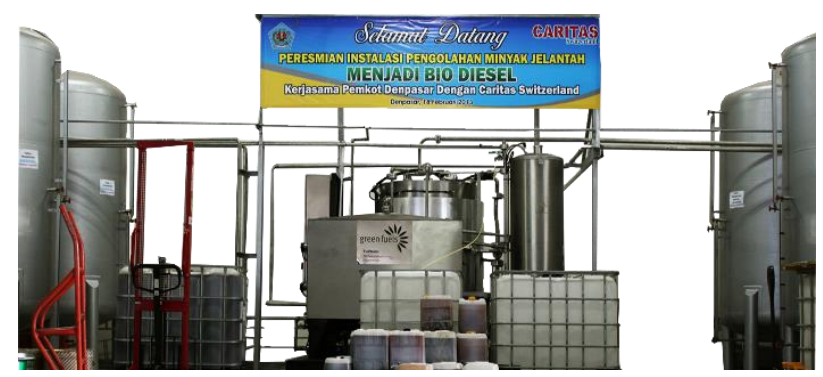

Fig. 3Biodiesel processing plant at YLH

\section{BUSINESS SUPPLY CHAIN}

YLH started its operation in 2013. The supply chain of biodiesel from used-cooking-oil is shown in Fig 4. In hotel kitchens and restaurants, a large volume of used cooking oil is regularly produced. In many developing countries this oil is disposed of uncontrolled to the environment that could pollute water bodies and also contribute to global warming. 


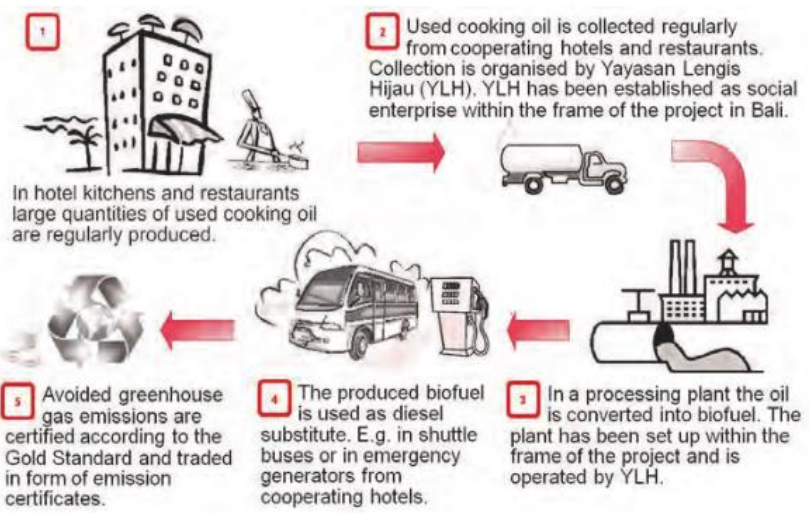

Fig. 4YLH supply chain of UCO to biofuels

The supply chain starts with the collection of UCO at the participating clients' premises and delivering it to YLH. In the factory, UCO is undergoing various processing stages before it turns into biodiesel. Biofuels are supplied to companies that are willing to use it as a substitute for their petroleum diesel fuels.

\section{YLH BUSINESS MODELS}

YLH has developed several business models that they currently operate and also plan to further develop from what they have achieved so far. They create five models that contain common elements for all models and some added value elements as a distinctive feature for each model.

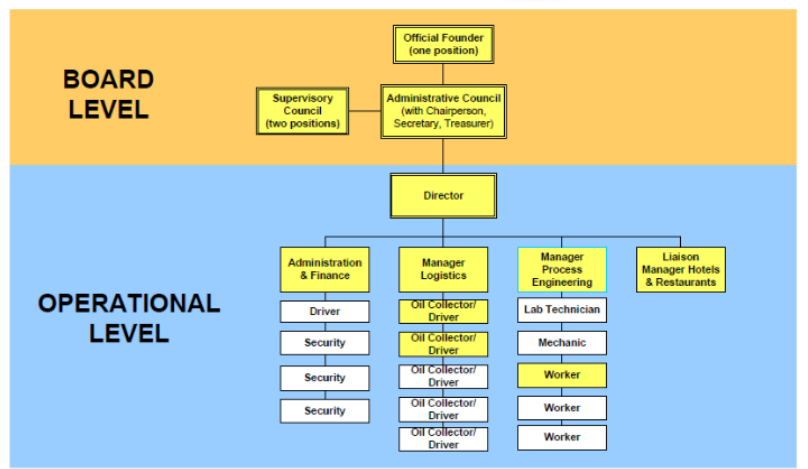

Fig. 5 Organization structure of YLH

\section{YLH Model \#1 \\ CONVENTIONAL FROM UCO INTO BIODIESEL(Compensate UCO Sell Biodiesel)}

This model is a conventional scheme that consists of core business activities:
1. UCO collection
2. Converting UCO into biodiesel
3. Biodiesel supply

These three core elements are common for each model. Whilethe high added values identified as part of this model are as follows:

1. UCO Compensation

2. Proper waste management and

3. Public health and environmentally friendly, and Green \& Clean energy Branding

4. Certificate of Participation

5. CSR Right to Claim

\section{YLH Model \#2 \\ EDUCATIONAL \& SOCIAL ENTREPRENEURSHIP SUPPORTS, GREEN SCHOOL BIOBUS}

On this model, it also contains the core business of YLH as described in Model \#1.

And the high added value identified from this educational and social entrepreneurship are:

1. UCO Compensation

2. Proper waste management

3. Public health and environmentally friendly, and Green \& Clean energy Branding

4. CSR Right to Claim

5. Carbon Emission Reduction

6. Educational/Integrated into the curriculum

7. Youth Power Mobilization

a. Experimental youth challenges project

b. Community outreach

c. Local \&international campaign

8. Students Social Enterprise Support

9. Mutual cooperation to access international funding

10. Public advocacy

This model has been developed in cooperation with the BIO BUS project with Bali Green School.

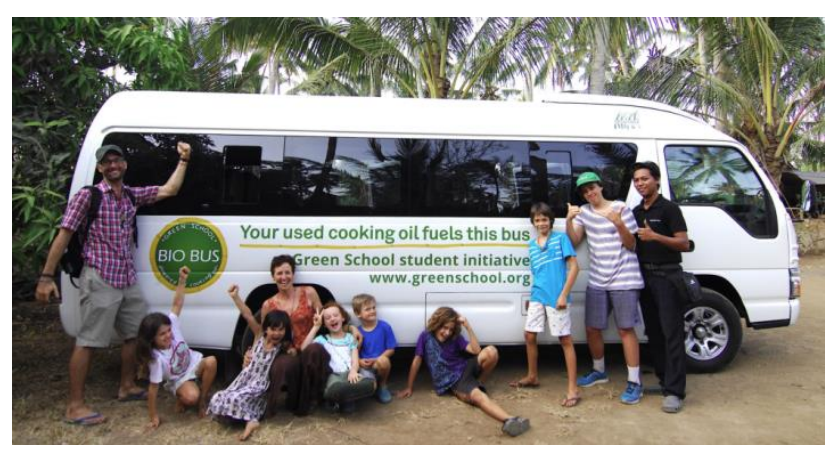

Fig. 5School bus fueled by UCO biofuel 


\section{YLH Model \#3 Cooperation WITH COMMUNITY (UCO Collection through community group and Trash Collector)}

This model is developed in cooperation with BanjarLiligundi, PPLH's Depot Cemarain November 2015. It contains the common elements of core activities.

The high added value derived from these models are:

1. UCO Compensation

2. Proper waste management and Public health and environmentally friendly, and Green \& Clean energy Awareness

3. Community/Women Involvement

4. Networking and Join Campaign cooperation with Other Local NGO

\section{YLH Model \#4 BARTER FROM UCO INTO BIODIESEL (Barter/ Exchange UCO With Biodiesel)}

This model has been developed in cooperation with VICEROY since February 2016. It contains key elements of the core business.

The high added value associated with this model are:

1. UCO exchange with Biodiesel (No Financial Transaction)

2. Proper waste management

3. Public health and environmentally friendly, and Green \& Clean energy Branding

4. Certificate of Participation

5. CSR Right to Claim

6. Networking with 3rd Party (eco-Mantra)

\section{YLH Model \#5 GENERATOR RENTAL POD CHOCOLATE}

This model is currently being developed and therefore has not yet been implemented. It will contain the common core business elements and with high added values as follows:

1. Green Generator Services

2. UCO Compensation

3. Proper waste management

4. Public health and environmentally friendly, and Green \& Clean energy Educational Branding

5. CSR Right to Claim

6. Green and Clean Energy Promotion - Integrating the program into Customers tours Packet Product

7. Increase Customer Product Value

8. (Quality Testing) Field Laboratory

9. (another business unit) Strategic Income

\section{COLLECTION, PRODUCTION, and DISTRIBUTION}

YLH started its operation in February 2013 and as of December 2015, UCO collection had reached 342,428 liters with a yearly breakdown is shown in Fig 6 . The distribution of biodiesel has reached a total of 569,034 liters of which 269,284 liters are distributed by YLH and 299,750 liters by AMO.

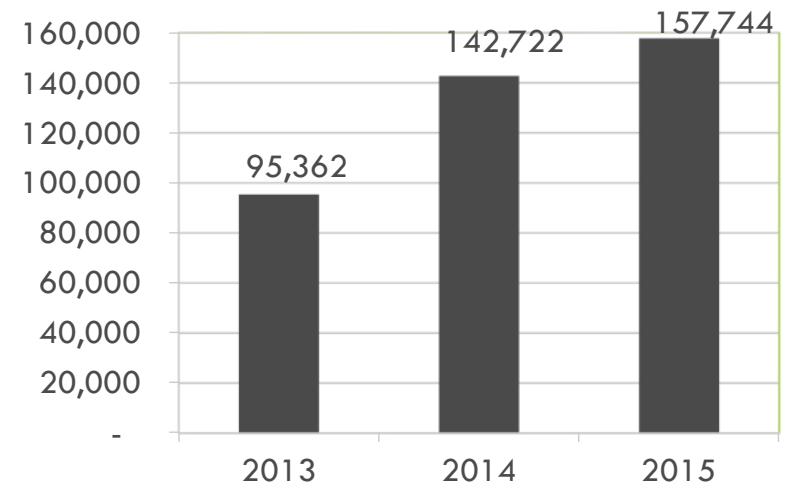

Fig. 6 UCO collection for three years

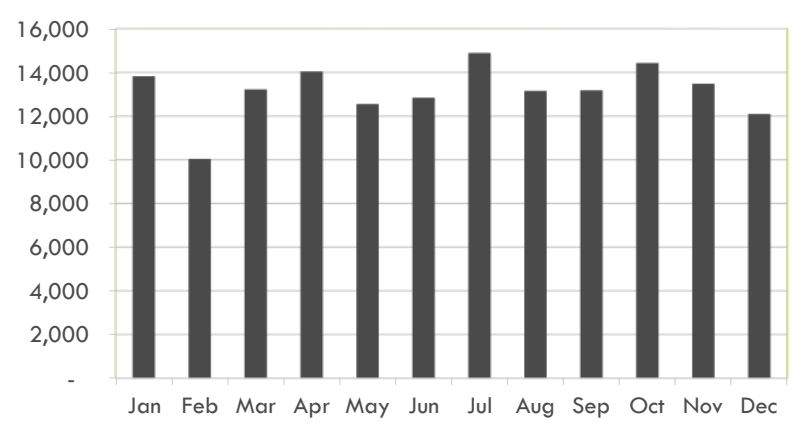

Fig. 7 Monthly UCO collection

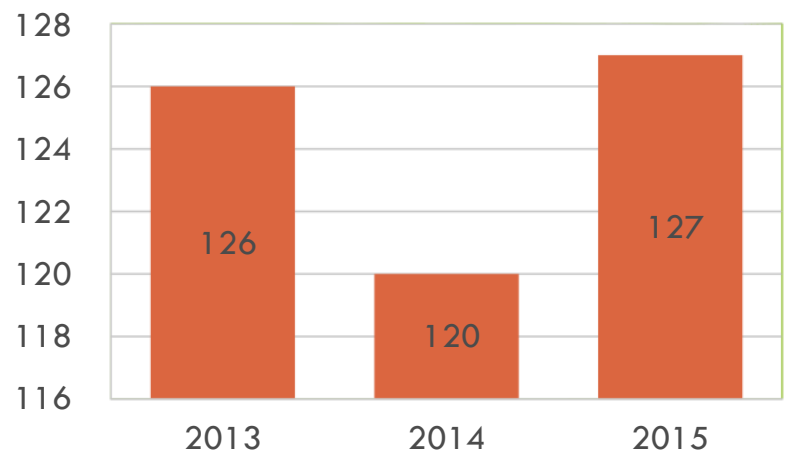

Fig. 8 Number of participating UCO clients 


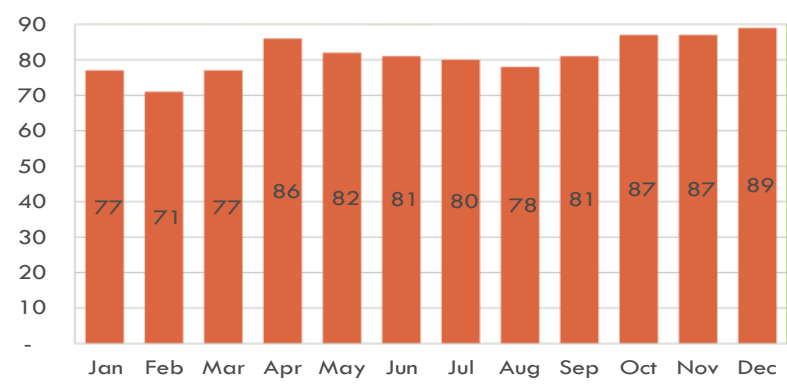

Fig. 9 Monthly UCO production

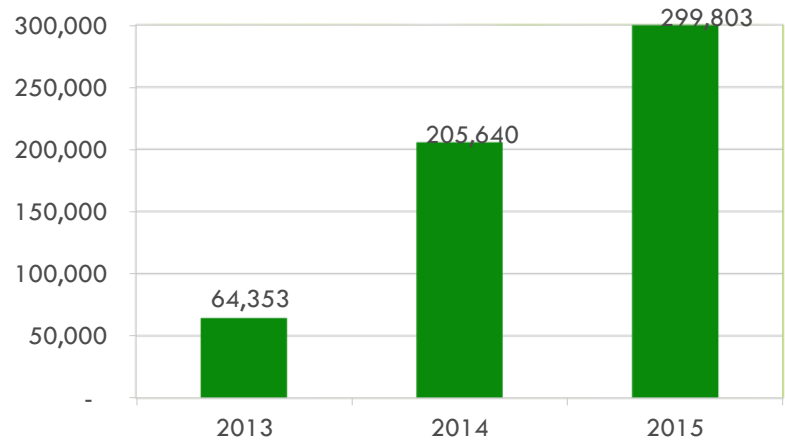

Fig. 10 Biofuel distributed to clients

\section{EDUCATIONAL ACTIVITIES}

Many visitors have come to YLH to learn more about the conversion of used-cooking-oil into biodiesel. From school pupil, university students, academics, researcher, district governments from many parts of Indonesia, including national agencies such as ICCTF, BPPT, BAPPENAS, RANGRK and GIZ, Fig 11 shows student learning in the factory.

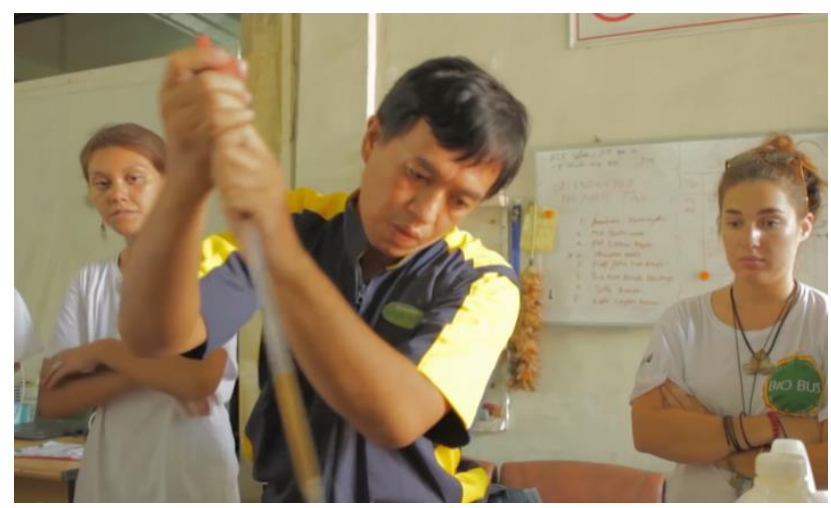

Fig. 11 School children learning

\section{CHALLENGES}

After nearly three years in operation, YLH has experienced success and also facing many challenges. The challenges are illustrated in Fig. 12.

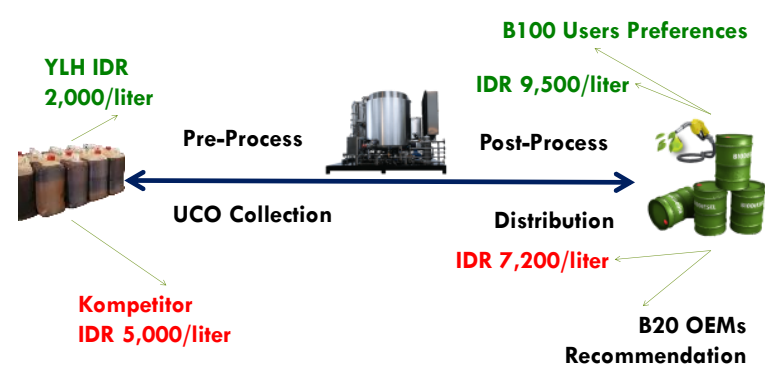

Fig. 12 Illustration of challenges

The continuous decline of industrial petroleum diesel price makes the biofuel produced by YLH faces a difficult competition. For example, the cost of YLH B100 is IDR 9,500 per liter while the cost of petroleum diesel is IDR 7,200 per liter and fluctuates but downward.

Currently, there is no regulation concerning the direct use of biodiesel B100 as fuels for diesel engines both used in electric power plants or transportation. Indonesia is currently focused on B10 and B15 and plans to adopt B20 and $\mathrm{B} 30$ in the future. Because of no regulation on the use of B100, the automotive industry and dealers throughout may withdraw the guarantee of the engines due to the use of unspecified fuels.

The requirement for biodiesel as a substitute for petroleum diesel fuel is described on Indonesian National Standard SNI \#04-7182-2006. This guideline provides terms, quality standards, test methods, and requirements for compliance, and including storage or packaging of biodiesel fuel. This has not been achieved by YLH biodiesel products, therefore, it requires laboratory tests and validation as to how much YLH biodiesel has met the required standards and plan to meet the standards should test results required so.

Initially, many of UCO participating clients provided the raw material provide it for free but that has no longer the case as this is now seen as a source of revenue although not formally but at least by related parties or personnel involved at the collection point as this perhaps associated with additional jobs to them. The UCO has to be acquired at the cost of IDR 2,000 per liter. However, it appears that UCO is also sourced by other parties and offered a higher 
price of IDR 5,000 per liter. Although UCO is widely available it is difficult to obtain due to those reasons. Currently, no regulation is in place concerning the UCO waste management. Also, the government has no program to address the risk of UCO if used in the food supply chain.

The process of turning UCO into biodiesel requires chemical materials known as a catalyst. The cost of the catalysts is still expensive. YLH has no capacity nor facility to develop or identify substitute material that could serve the same purposes as the current catalyst used.

Table 1 Number of Hotel in Bali 2013

\begin{tabular}{|c|c|c|c|c|c|c|c|}
\hline \multirow{2}{*}{\multicolumn{2}{|c|}{ District }} & \multicolumn{5}{|c|}{ Class of Hotel (number of star) } & \multirow{2}{*}{ Total } \\
\hline & & $* * * * *$ & $* * * *$ & *** & ** & * & \\
\hline 1 & Jembrana & 0 & 0 & 2 & 0 & 0 & 2 \\
\hline 2 & Tabanan & 2 & 0 & 0 & 0 & 0 & 2 \\
\hline 3 & Badung & 40 & 46 & 37 & 12 & 11 & 146 \\
\hline 4 & Gianyar & 6 & 7 & 3 & 1 & 1 & 18 \\
\hline 5 & Klungkung & 0 & 0 & 4 & 1 & 2 & 7 \\
\hline 6 & Bangli & 0 & 0 & 0 & 0 & 0 & 0 \\
\hline 7 & Karangasem & 1 & 2 & 2 & 1 & 1 & 7 \\
\hline 8 & Buleleng & 1 & 2 & 8 & 2 & 1 & 14 \\
\hline 9 & Denpasar & 4 & 5 & 7 & 7 & 8 & 31 \\
\hline \multicolumn{8}{|c|}{ Total Number } \\
\hline & 2013 & 54 & 62 & 63 & 24 & 24 & 227 \\
\hline & 2012 & 52 & 59 & 59 & 25 & 23 & 218 \\
\hline & 2011 & 51 & 53 & 52 & 23 & 19 & 198 \\
\hline & 2010 & 37 & 48 & 35 & 26 & 9 & 155 \\
\hline & 2009 & 37 & 41 & 35 & 27 & 9 & 149 \\
\hline
\end{tabular}

Source: Bali in Figures 2014

Despite a large number of hotels and restaurants in Bali and although they might have had a relatively good understanding of the subject of clean and green campaigns to actually participating in the programs requires a long process. Therefore, commitment to clean and green programs need to be strengthened.

Another concern is the performance test on engines that uses B100. Currently, the information in this regard is based on the experience of their clients such as from bus drivers who told them that they do not experience diminishing of drive power of their bus after using B100. Although this information is encouraging it needs to be verified by a laboratory test.

\section{RECOMMENDATION}

- The declining oil price has become one of the inhibiting factors for the market expansion of biofuels or any other energy forms generated via renewable technology. Therefore, the government should introduce incentives for biofuels and UCO-based biofuels in particular. The incentives could be in the form of price subsidy, tax incentives for biofuels users, or any other form.

- One solution to overcome matters related to the nonexistence of regulation concerning B100 is to produce alternative biodiesels with composition currently covered by the regulation. For example, instead of the single product of $\mathrm{B} 100$, other biodiesel mixes such as B10 or B15 as the automotive industry has prepared their products, i.e. cars engine to use that biodiesel mix. However, to get final products that meet the SNI requirement, it has to be tested in the laboratory. In this regard, the Laboratory of Material and Energy Conversion of Department MechanicalEngineering Udayana University is ready to cooperate.

- Local Government needs to set up a task force to look in detail regarding UCO management as the substance is available in large volume and it poses risks to health and environments. The Badan Lingkungan Hidup City of Denpasar is the agency that closely related to this matter.

- In a wider view, the Government of Bali needs to establish a department or council that especially working in the field of new and renewable energy (NRE). Currently, the Government only has sub-council and is part of the Department of Public Works while nationally this ministry is the ministry that has a major contribution to the state revenue.

- Campaign and socialization among hotels, restaurants, schools, local government agencies, estate managers, and the like should be continued taking any momentums or events so people are well informed with YLH and problems associated with UCO. For example, CORE will facilitate FGD with ITDC/ BTDC that manages the world-class Nusa Dua tourism complex.

- Close collaboration with Environmental Agencies in Bali, CORE or Udayana University can potentially overcome several of the challenges. For example, performance tests, identifying new catalysts preferably of local material, re-engineering of an existing processing plant to allow for more components of locally sourced parts or components of the plants. 


\section{ACKNOWLEDGMENT}

This Policy Brief produced by Konsorsium "PETUAH" Perguruan Tinggi untuk Indonesia Hijau and funded by the Millenium Challenge Account (MCA) Indonesia

\section{REFERENCE}

Green School, "The Bio Bus Story: Solution Based Learning, Community Engagement Enterprise," 2015

MEMR, Regulation of MEMR \#25/2013 concerning Supply, Utilization, and Business of Biofuels as Other Fuel, MEMR, 2013

Green Fuels Ltd, "Fuelmatic GSX Range: Product Description," Green Fuels Ltd, 2013

The Gold Standard, "The Gold Standard Micro-Scale Project Document Design Form 2.2," The Gold Standard Micro Climate

E. Setiawan, "Used-Cooking-Oil (UCO) turned into B100 Biofuels," Focus Group Discussion CORE, Denpasar, 2016

Environmental Protection Agency, "Waste Cooking Oil to Fuel Program: How to Start Your Won Biofuel Program," available at www.rit.edu

Refaat, A.A., "Different Techniques for the Production of Biodiesel from Waste Vegetable Oil," Int. J. Environ. Sci. Tech. 7(1), 183-213, Winter 2010, ISSN: 17351472. 